\title{
MARONITE GARSHUNI TEXTS: ON THEIR EVOLUTION, CHARACTERISTICS, AND FUNCTION
}

\author{
JOSEPH MOUKARZEL \\ HOLY SPIRIT UNIVERSITY OF KASLIK (LEBANON)
}

\begin{abstract}
This article aims to study the history of Maronite Garshuni which is basically the Arabic language written in Syriac letters. For a very long time after the conquest of Islam, the Maronites have used Syriac for Sacred books and liturgical affairs and Garshuni for other matters. The use of Garshuni seems to be first and foremost an issue of practicality because at first Maronites, like other Syriac Christians, began to speak colloquial Arabic and were unable or scarcely able to write it. The other functions of Garshuni, like cultural, religious or national, were deduced later.

Until recently, there was a wide belief that the Maronites were behind the invention of Garshuni, or, at least, that the Maronite milieu played a leading role in the emergence and development of this system. This claim is no longer accepted, as many West Syrian manuscripts written in Garshuni serto are older than Maronite ones. The oldest Maronite Garshuni notes go back to the $12^{\text {th }}$ century, while the oldest dated manuscript is from 1402 A.D. The Maronites used Garshuni for many literary genres and contributed to its etymological hypotheses.

Furthermore, the Maronites used Garshuni in inscriptions and in their printed texts until late $20^{\text {th }}$ century. Nowadays, we witness a "reverse Garshuni" in the Maronite liturgical books when many
\end{abstract}


Syriac texts are transcribed in Arabic letters to assist the full participation of the people during the liturgy.

While it is true that Garshuni is a transcription system, it did not generate complex grammar, but rather simple general rules, adopted by copyists throughout the ages, depending on the cultural background, religious tradition, and geographical location of each of these copyists. Nevertheless, Maronite Garshuni improved during its evolution, varieties, and specificities.

\section{INTRODUCTION}

The field of Garshuni studies was considered for many years as a supplement to Syriac or Arabic studies. Catalogers used to include Garshuni manuscripts within the catalogues of Syriac ${ }^{1}$ manuscripts, and scholars in Arabic literature usually study the Arabic content of the Garshuni manuscripts without any attention to the Garshuni script itself.

Despite many minor articles about Garshuni written at the end of the $19^{\text {th }}$ century and during the $20^{\text {th }}$ century, ${ }^{2}$ the scientific work about Garshuni began only late in the $20^{\text {th }}$ century, prior to becoming an independent subject in the last few years. ${ }^{3}$ Meanwhile,

${ }^{1}$ Most of the traditional catalogues described Garshuni manuscripts with Syriac manuscripts without any mention of Garshuni in the title, like the catalogues of the Vatican library (ASSEMANI 1756-1759, MAI 1831, VAN LANTSCHOOT 1965), the Medicean-Laurentian Library in Florence (Assemanus 1742), the National Library of France (ZOTENBERG 1874, Briquel Chatonnet 1997), Berlin (SACHAU 1899), Cambridge (WRIGHT 1901), and the British Library (Wright 1870-1872). Only few of them mention Garshuni in the title, like the catalogues of Birmingham (MinganA 1933), the British Library (ROSEN and ForSHALL 1838, Margoliouth 1873), Oxford (Smith 1864), Aleppo (Río SÁnCheZ 2010), and Iraq (HARRAK 2011).

2 Diryan 1904, Brockelmann 1927, Mingana 1928, BakHache 1936.

3 The two main articles about Garshuni are still ASSFALG 1982 and BRiQuel CHATONNET 2005. Among the other valuable works on Garshuni, Troupeau 1978, SAlem 1988, Assfalg 1991, CoAkLey 2001, Río SÁNCHEZ 2004, MENGOZZi 2010, BRAIDA 2010, BRAIDA 2011, MENGOZZI 2011, KESSEL 2012. In our article (MOUKARZEL 2014), we try to review all hypotheses about the history and the etymology of Garshuni. 
scholars tried to identify many 'genres' of Garshuni both for its confessional identity ${ }^{4}$ and for its application to specific languages. ${ }^{5}$

According to this classification, the current paper aims to study Maronite Garshuni, which means how, when, and for which purposes the Maronites used Garshuni. ${ }^{6}$ It is safe to say that Maronite Garshuni is basically Arabic-Syriac Garshuni. Other forms of Garshuni only occasionally appear in Maronite manuscripts:

-Greek-Syriac Garshuni notes in some Maronite manuscripts copied and used in Cyprus $^{7}$ where a small Maronite community is still active.

-Turkish-Syriac Garshuni in one manuscript. It is a Book of Prayer, usually used by lay people, copied by the Maronite Antonyos of Ghosta in $1750 .{ }^{8}$

-Latin-Syriac Garshuni found in some manuscripts and used to transcribe Latin hymns or prayers into Arabic. ${ }^{9}$

\section{THE FUNCTION OF GARSHUNI}

The role played by Garshuni in the daily life of Syriac Christians is summarized in the description of the Maronite patriarch Stephan Douaihy: "The people adopted Syriac for sacred books and Garshuni to transliterate the spoken language of Arabic." 10

${ }^{4}$ Melkite, West Syriac, East Syriac, Maronite, etc.

5 Arabic, Armenian, Turkish, Kurdish, Malayalam, etc. Useful references cited by ASsFALG 1982: 299-300 and MENGOZZI 2008: 297, n. 2.

6 Many works deal with Maronite texts in Garshuni like JABREMouawad 2005, MengozZI 2008, Braida 2009, Braida 2010, Borbone 2010, BrAIDA 2012, JABre-MoUAWAD 2012, and Río SÁNCHEZ 2013.

${ }^{7}$ For example, the readers' notes at the end of ms. Florence, BML Or 411.

8 Oxford Bodlean Or 668.

${ }^{9}$ For exemple, ms. Vatican, BAV, Vat Syr 477, f. 116v (Ave Maria).

10 In a letter, dated on August $8^{\text {th }}$ 1673: "In quanto alla lingua, ch'adopriamo ordinariamente nelle cose Sacre, è la lingua Siriaca, chiamata anticamente la Caldea, se bene si ritrova in ambidoi qualche differenza accidentale nelle vocali; ma nel discorso commune trà il volgo adopriamo la lingua Araba, se bene nello scrivere ordinariamente adopriamo li caratteri Siriaci, tanto che le voci Arabi, scritte in Siriaco, si dicono 
But why this need for Garshuni? One of the oldest explanations of the function of Garshuni dates back to 1596, in Georges Amira's Syriac grammar. He wrote:

Seeing as Christians lived amongst infidels and that Arabic was a language both people shared, the former came up with the idea of writing their sacred words and rituals in Syriac alphabet, something the infidels could not read. Many books were written in that manner for protection against the infidels' horrid morals and fake religion. If these books had been written in Arabic alphabet, the Christian faith would have been in great danger. However that may be, it is true that Arabic is to Syriac today what Italian is to Latin. Italian is written in Latin letters and Arabic is written by the Christians, in general, in Syriac letters, even though it has its own alphabet, as previously mentioned. As a result, both Testaments and other holy books, along with grammar books, dictionaries, poems and a number of books and other works of art were written in that language, but using the Syriac alphabet. This is the reason why any book amongst those pertaining to an honorable and illustrious science can be read and understood by us. ${ }^{11}$

As such, Garshuni may play a cultural function, ${ }^{12}$ to conceal "Christian books from infidels' eyes." Hence, many scholars suggest that Garshuni constitutes a sort of "national and religious

Carsciuni; come si stà notato da Giorgio Amira nella sua Grammatica Sira-Latina." HunTINGTON 1704: 103.

11 AMIRA 1596: 23.

12 Mengozzi argues the ideological role of Garshuni and gives the Maronites as example for whom "a more relevant motivation may be found in the need to assert and strengthen the cultural identity of a community, whose traditional language and culture are challenged or even endangered by a dominant language." He supports his theory by citing the Hebrew script used by Jews in various languages (Judeo-Arabic, Yiddish, Jewish Neo-Aramaic, sometimes Ladino and Judeo-Spanish). MENGOZZI 2010: 299. 
identity" 13 for Christian minorities to preserve their own religious heritage. ${ }^{14}$ In addition, other scholars consider that the use of Garshuni implies a total mastering of Arabic. ${ }^{15}$

These hypotheses require an explanation. The use of Garshuni seems to be first and foremost an issue of practicality. Under Arab rule, Syriac Christians, Maronites, and others at first began to speak colloquial Arabic and were unable, or scarcely able, to write it. Most of them preferred to transliterate Arabic works in Syriac characters, "so as to be able to read them with greater ease." 16 Through the years, two types of Arabic were confirmed by manuscripts: Middle Arabic, as studied by Blau ${ }^{17}$ and others, and colloquial. ${ }^{18}$

13 "Una escritura propia, un elemento de identidad nacional y religiosa." Río SÁNCHEZ 2004: 187. Braida states that "Some scholars, for example Brockelman to some extent Lenormant and much more recently Del Rio Sanchez suggested there might be an ideological motivation underlying the birth of the Garshuni system, based on the need to assert the social and religious identity of the Syriac community, whose traditional culture was challenged by the spread of the dominant Arabic language." BRAIDA 2012: 187.

14 "It is evident that Arabic was the language of their everyday life; else why should the rubrics be in Karshuni? Religious communities, especially when they are in the midst of a people hostile to their faith, are apt to cling tenaciously to the use of the dead language of their fathers." LEWIS and GIBSON 1899: xv.

${ }^{15}$ Río SÁNCHEZ 2004: 187. Mengozzi adds that the use of Garshuni "requires a high degree of literacy in Arabic as well as a wide acquaintance with the grammar and lexicon of the language." MenGOZZi 2010: 299.

16 According to Blau, "the cultural symbiosis of medieval Jews and Arabs was, as a rule, not the achievement of individual Jews and Muslims, but of Jewish and Arab social groups. Therefore, generally speaking, the barriers between the two cultures remained. One of the outward marks of this separation was the fact that the bulk of Jewry, bar the intelligentsia, could scarcely read Arabic characters: they used, in the writing of both Hebrew and Arabic, their Hebrew script. They would even transliterate works by Muslim authors into Hebrew characters, in order to be able to read them with greater ease." BLAU 1981: 35-36.

${ }^{17}$ BLAU 1981 and all his publications on this matter.

${ }^{18}$ Samir argues that "généralement, les manuscrits garšūnīs dénotent une moindre connaissance de la langue arabe, de la part des copistes. Ainsi, le Vatican syriaque 133 fourmille-t-il d'erreurs de lecture, qu'un scribe moyen ne ferait pas." SAMIR 1982: 45. Another example is found in 
For these reasons, it seems inaccurate to claim that Maronites did not adopt Garshuni until the $15^{\text {th }}$ century. ${ }^{19}$ The Maronites, as other Syriac Christians, used Garshuni to produce Arabic literature, and we do not actually know when they became "fully arabized." 20 In any case the Garshuni script was their predominant tool of writing until the beginning of the $20^{\text {th }}$ century.

Examples abound in the history of Maronites, as the following excerpts show:

-In a paragraph written in Arabic in 1565, Sarkis Rizzi declared his ignorance of that language. That is why his Arabic is very poor and the Garshuni way of transcribing prevails in his writing. ${ }^{21}$

-Onboard his ship (between April and June of 1578), the papal envoy J.-B. Eliano tried to give the Maronite bishop George a little reading and writing exercise in the Arabic alphabet instead of Garshuni. ${ }^{22} \mathrm{He}$ also noted that he found

ms. BnF Syr 237, (dated from 1553), where the scribe Ibrāhīm declared he transliterated the book from Arabic into Garshuni without even knowing the Arabic language. ZOTENBERG 1874: 190.

${ }^{19}$ Samir gives as example the Book of Direction which was first written in Arabic then in Garshuni (during 15-19 centuries), and finally in Arabic again (19 ${ }^{\text {th }}$ c.). He concludes by saying, "l'écriture garšūnie semble prendre naissance à l'époque de décadence de la culture arabe (eașr al-inhițāț), à partir du XVe siècle. Auparavant, c'est encore l'arabe qui est seul utilisé (ou qui prédomine). Au XIX ${ }^{\mathrm{e}}$ siècle, à l'époque de la renaissance arabe (la Nahḍah) lancée précisément par les Maronites, c'est de nouveau l'arabe qui seul apparait chez eux." SAMIR 1982: 43.

20 JABRE-MOUAWAD 2012: 226, claims that “in Crusaders' time (12-13 centuries), the Maronites were still using Syriac not only for their liturgical celebration, but in their everyday life as well."

21 BAV Borg Ar 135, f. 26v. The differences between the Arabic writing of Sarkis, the standard writing of the same words in Garshuni and the classical Arabic are:

\begin{tabular}{|c|c|c|}
\hline Garshuni & Classical Ar. & S. Rizzi \\
\hline لده & على & علي \\
\hline סे & ضعفى & ظعفى \\
\hline ofo & وضع & وظع \\
\hline احتئ| & النصارى & النصار ا \\
\hline IN & حتى & حتا \\
\hline
\end{tabular}

${ }^{22}$ KURI 1989: 78*. 
only one copy of the Bible written in the Arabic alphabet in the Maronites' possession. ${ }^{23}$

-The official version of the decrees of the Maronite Synod held at the monastery of Qannoubine in 1580 was written in Latin, whereas the Arabic translation was made only in Garshuni.24 The by-laws of the Maronite College of Rome, written in 1585, are also attested in Latin-Garshuni versions. ${ }^{25}$

-In the preface of the Maronite Śbiyeh, published in Rome in 1782, the editor, Sarufim Shushan, stated that he worked on printing the book in Garshuni "for the profit of those who cannot read Arabic letters."26

-Until recently, it was common practice to read the Epistle and the Gospel in Garshuni in Maronite churches. ${ }^{27}$ This was due to the fact that readers had learned to read Garshuni, not Arabic, in religious schools in the mountains.

-This lack of knowledge of the Arabic language prompted the major Maronite Synod of 1736, known as the Lebanese Synod, to promulgate decrees about teaching the youth "the reading and writing of Arabic and Syriac."28 The later synods of $18^{\text {th }}-19^{\text {th }}$ centuries continued to encourage this practice, but prohibited to write any liturgical book in Arabic letters. ${ }^{29}$

\section{THE MARONITE LITERATURE ON GARSHUNI SCRIPT}

\subsection{Use of the word "Garshuni"}

Even if, according to the most recent research, we could date the oldest texts written in Garshuni script back to $9^{\text {th }}-10^{\text {th }}$ century, ${ }^{30}$

23 KURI 1989: 122*.

${ }^{24}$ Feghali 1962: 104.

${ }^{25}$ GEMAYEL 1984, I: 45.

${ }^{26}$ SHUSHAN 1782. The quote is cited in KURI 1989: $78^{*}$, n. 15.

27 The last Garshuni edition of the Epistle, printed in 1907, was still in use in many rural Maronite churches until late 1960s.

${ }^{28}$ Lebanese Synod, part 6: 3/3 (p. 535), 5/6 (p. 546), 7 (p. 551).

29 Synod of Qannoubine (1755), Synod of Beq ātā (1756). See FEGHALI 1962.

30 Briquel-Chatonnet, Desreumaux and Binggeli 2006; MOUKARZEL 2008. 
the word "Garshuni" did not appear until the $16^{\text {th }}$ century ${ }^{31}$ since the oldest known presence dates back to 1516 under the spelling "Garshuni." 32

The first known Maronite to make use of this term is Sarkis of Smar Jbeil, a famous Maronite scribe (late $16^{\text {th }}$-early $17^{\text {th }}$ century). ${ }^{33}$

Sometimes Maronite authors do not call Garshuni by its name. In the Grammatica Syriaca, edited in 1596, Girgis Amira defined this way of writing as " the use of the Syriac alphabet to write Arabic." 34 However, the use of the term Garshuni is observed more frequently in the Maronite manuscripts since the $18^{\text {th }}$ century.

\subsection{Spelling}

Both spellings "Garshuni" and "Karshuni" are mentioned in Maronite manuscripts with preference for the Karshuni version. An odd spelling, Akarshuni (صori), is only used once. ${ }^{35}$ In the

31 BL Or 8729, f. 1r. Braida (2012: 193) notes that the oldest manuscript where she found the term "Garshuni" is the BAV Vat Syr 207, containing sermons by John of Daliatha. It is written in 1492 by Ephrem from Sadad who "transcribed it from Arabic to karshuni in the monastery of Holy Virgin, in Wadi Habib" (f. 255b). We consider that this statement needs clarification. The copyist Ephrem wrote only that he transcribed the book from Arabic (f. 255r). Another hand added a note, in Arabic, at the end of the colophon to say that "he [Ephrem] transcribed it from Arabic to Karshuni." This note is undated and the Arabic calligraphy seems not to be so old (1492) and even more recent than the other Arabic note penned at the last folio of the codex (f. 265v).

${ }^{32} \mathrm{BL}$ Or 8729 (copied in 1230; it is not yet catalogued). On the f. 1v, Gregorius, Syriac bishop of Jerusalem, provides, in 1516, a list of all the works written by the monks of the monastery of Maria Deipara in the Nitrian Desert (Egypt). Between these works, he mentions many manuscripts written in "Garshuni." About this manuscript and this collection, see LEROY 1967.

33 A note inserted in ms. BL Egerton 704, f. 77r. About Sarkis, see MOUKARZEL 2007: 484.

34 "De usu litterarum Chaldaicarum in scribendum linguam Arabica." AMIRA 1596: 22.

35 Cited in Wright, 1870-1872, I: 2. It is the note of Sarkis, mentioned above. 
scholarly milieu, Maronites traditionally used to adopt the initial letter " $C$ " for Latin characters, ${ }^{36}$ and " $\mathrm{K}$ " in Arabic.

\subsection{Etymological hypotheses}

Ten etymological hypotheses could be identified about the word Garshuni. ${ }^{37}$ The oldest among them comes from a Maronite, Faustus Naironus, who, in the preface ${ }^{38}$ of the New Testament published in Rome in 1703, said:

Carsciun, a Syriac of Mesopotamia, started writing Arabic using the Syriac alphabet to make it easier for Syriac people to learn how to read Arabic, a language brought to Syria by the Saracens. ${ }^{39}$

The Assemanis, for their part, believed that Garshuni meant "foreigner" or "exotic." 40 Another Maronite, Joseph Diryan, wrote that contrary to the large and square estrangelo script, the Garshuni script is "the rounded shape" used by the western Syriac tradition.

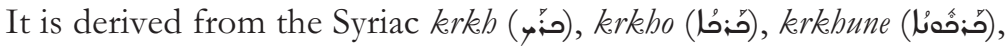
which means "small circles;" hence, these smaller shape circles were called karkhuni, which would later become karshuni. ${ }^{41}$

Other hypotheses have also been adopted but are less used than these mentioned above.

36 Carsciune: The Maronite patriarch Stefan Douaihy in a letter dated from 1673. See Huntington 1704: 103. Charsciuni: NAIRONus 1703, Latin introduction: 2 and 10 [No original pagination]. Carsciuni: ASSEMANUS 1742: 51; ASSEMANI 1756-1759, II: 23.

${ }^{37}$ See MOUKARZEL 2014.

38 Assemanus 1742: 51, attributed this preface to both Naironus and Gabriel Sionita (died in 1648)! This mistake was reproduced in ASSEMANI 1756-1759, II: 23, and followed by many authors. It happens also that scholars, like Mingana, omitted Naironus and attributed this preface to only Sionita. See MiNGANA 1928: 891.

39 NAIRONUS 1703, Latin introduction: 2 and 10 [No original pagination].

40 Assemani 1756-1759, II: XXIII-XIV: “ [...] a voce, quae adventitium sonat, Garscionici, seu Garscimnici, i.e. Exotici, ac Peregrini, vulgo nuncupantur."

${ }^{41}$ DIRYAN 1904. 


\subsection{Calligraphy}

No estrangelo Garshuni has yet been discovered in the Maronite manuscripts. Thus, Maronite Garshuni is always written in serto, except for some cases where titles or special words are written in estrangelo ${ }^{42}$ to distinguish them from the rest of the text.

We do not know if the absence of estrangelo in Garshuni manuscripts could is the result of more general practice. According to Briquel Chatonnet the only known estrangelo Garshuni is a recipe, probably written by a West Syrian, and conserved in the BL Add. $14,644.43$

\subsection{Literary genres}

Texts written in Garshuni and used by the Maronites almost cover all genres: ${ }^{44}$ Bible ${ }^{45}$ and Bible commentary, ${ }^{46}$ liturgy, ${ }^{47}$ hagiography, ${ }^{48}$ theology, ${ }^{49}$ patristic, ${ }^{50}$ sacraments, ${ }^{51}$ catechism, ${ }^{52}$ asceticism and monasticism, ${ }^{53}$ philosophy, ${ }^{54}$ canon law, ${ }^{55}$ history, ${ }^{56}$ astrology, ${ }^{57}$

${ }^{42}$ As in BAV Borg Ar 135.

43 Briquel-ChatonNet, DesreumauX and BingGeli 2006: 149.

44 We do not have any definitive inventory of Maronite manuscripts; that is why we give only some examples for each discipline taken from the collection of the Lebanese Maronite Order, preserved at the Holy Spirit University of Kaslik.

45 OLM 701 (1566), OLM 983 (1673), OLM 654 (1684), OLM 94 (1686), OLM 221 (1687), OLM 984 (1697), OLM 318 (1745), OLM 357 (1774), OLM 307 (1851).

${ }^{46}$ OLM 432 (18 $8^{\text {th }}$ c.), OLM 282 (1732), OLM 987 (1780), OLM 517 (1818), OLM 989 (1841), OLM 511 (1850).

47 OLM 103 (1517), OLM 132 (1688), OLM 33 (1738), OLM 1 (1792), OLM 40 (1844), OLM 56 (1898), OLM 122 (1916), OLM 154 (1965).

${ }^{48}$ OLM 145 (1767), OLM 63 (1780), OLM 108 (1940).

${ }^{49}$ OLM 113 (1735).

${ }^{50}$ OLM 669 (1707), OLM 1008 (1717), OLM 293 (1821), OLM 237 (1843), OLM 769 (1862).

51 OLM 39 (1705), OLM 260 (1713), OLM 134 (1805), OLM 54 (1826), OLM 38 (1839).

${ }^{52}$ OLM 295 (1741), OLM 32/1 (1742), OLM 737 (1855).

53 OLM 27 (1732), OLM 469 (1753), OLM 3 (1791), OLM 291 (1837), OLM 83 (1951).

54 OLM 525 (1736), OLM 484 (1737), OLM 339 (1843), OLM 88 (1854). 
medicine, ${ }^{58}$ alchemical and scientific texts, ${ }^{59}$ sermons, ${ }^{60}$ songs and poems, ${ }^{61}$ letters, ${ }^{62}$ account books, ${ }^{63}$ grammar books and thesauruses, ${ }^{64}$ controversies, ${ }^{65}$ treatises on morality, ${ }^{66}$ and treatises on spirituality ${ }^{67}$ and popular piety..$^{68}$

\section{THE TEXTS AND THEIR CHARACTERISTICS.}

\subsection{Timeline of Maronite Garshuni}

There was a wide belief that the Maronites were behind the invention of Garshuni, ${ }^{69}$ or, at least, that the Maronite milieu played a leading role in the emergence and development of this

55 OLM 692 (18 $8^{\text {th }}$ c.), OLM 745 (1824), OLM 656 (1830), OLM 29 (1841).

${ }^{56}$ OLM 647 (1842), OLM 792 (1863), OLM 814/2 (1873).

57 OLM 1492 (1834), OLM 814/1 (1843), OLM 766 (1879), OLM $735 / 2$ (1896).

${ }^{58}$ OLM 861 (1805), OLM 41/2 (1817), OLM 706 (1843), OLM 767 (1892).

${ }^{59}$ OLM 774 (19 th $\left.\mathrm{c}.\right)$.

${ }^{60}$ OLM 24 (1707), OLM 321 (1841).

61 OLM 146 (1789), OLM 658 (1872), OLM 230 (1895), OLM 420 (1931).

62 The administrative and personal letters belonging to the archives of the Lebanese Maronite Order (conserved now at the Holy Spirit University of Kaslik - Lebanon) and dated before the $20^{\text {th }}$ century, are mainly written in Garshuni.

${ }^{63}$ OLM 1419 (1726), OLM 3297 (19 th $^{\text {th }}$.).

${ }_{64}$ OLM 166 (1813), OLM 75 (1822), OLM 49 (1845), OLM 47 (1871), OLM 148 (1885).

${ }^{65}$ OLM 721 (1677), OLM 789 (19 th $\left.c.\right)$, OLM 136 (1819).

${ }^{66}$ OLM 232 (1700), OLM 31 (1820), OLM 16 (1857).

${ }^{67}$ OLM 35 (1731), OLM 32/3 (1742), OLM 71 (1771), OLM 322 (1827), OLM 289 (1843).

${ }^{68}$ OLM 85 (1808), OLM 177 (1858), OLM 26 (1870), OLM 79 (1928), OLM 223 (1940).

${ }^{69}$ RENAN 1863: 266 ; BLAU 1981: 42, n. 1; RiO SANCHEZ 2004: 187; MENGOZZI 2010: 298. On another side Diryan, according to his own interpretation of a section taken from the Annals of the patriarch Douaihy, argued that the serto script is round (in contrast to the squared estrangelo), and added that it was invented by the Maronites during the 14th century. DIRYAN 1904: 880. 
system. ${ }^{70}$ In this context, Widmanstetter noted in 1557 in a text concerning writing practices adopted by the Christians of the Orient that Garshuni was the system used by Maronites. ${ }^{71}$ This claim is no longer accepted, as many West Syrian manuscripts written in Garshuni serto are older than Maronite ones. ${ }^{72}$

Recent research distinguishes between two types of texts in Garshuni: short texts (colophons, headings, margin notes, later additions to texts, readers' notes, recipes...), and complete texts (letters, chapters, treatises, books). Researchers lean towards the $9^{\text {th }}$ and $10^{\text {th }}$ centuries for the oldest notes, and towards the $13^{\text {th }}$ and $14^{\text {th }}$ centuries for the oldest dated manuscripts containing complete texts.

\subsubsection{Notes}

Below, I will only mention the four oldest known dated Maronite Garshuni notes:

-The oldest Maronite note is from the $12^{\text {th }}$ century; it is a note written in $\mathbf{1 1 4 1}$ by the Maronite patriarch Ya'qūb of Rāmāt in ms. BAV, Vat Syr 118 (f. 252r; which contains homilies by Jacob of Serugh).

-1154, the date of the oldest note found in Rabbula's Book of Gospels. It is written by the Maronite patriarch Buțrus (Firenze, BML, Pluteo 1.56, f. 7v) . ${ }^{73}$

70 BRAIDA 2012: 186.

71 Böbzin was the first to draw attention to Widmanstetter's note in ms. München Ar. 1058 (undated but certainly written before 1557). Entitled Quadam grammatica Arabica annotationes, this manuscript is an autograph of Johann Albrecht von Widmanstetter (†1557), editor of the first printed Syriac New Testament in Europe (Vienna 1555). The word Garshuni is written in Hebrew with a $[\mathrm{q}]$, instead of $[\mathrm{k}]$ or $[\mathrm{g}]$ : "aliam postremo Christianis quos Maronitas vocant, qui Chaldaico sermone in sacris utuntur, arabico vulgo passim, hunc ipsi vocant קרשוני [Qršūnī] illum Chaldaicum quem Syrum adpellant” (f. 20v). BOBZIN 1991: 261.

${ }^{72}$ Mardin Orth. 196 (1293/4; a part in Garshuni); BL Add 14.722

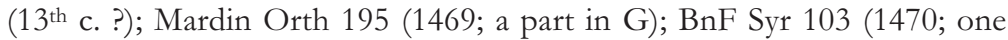
folio only); Mardin Orth 420 (1471/2; a part in G); BAV VS 562 (1487; a part in G); BAV VS 207 (before 1492). See also KESSEL 2012.

${ }^{73}$ Edited by MENGOZZI 2010: 302, who gives a list of all other notes dated before the $15^{\text {th }}$ century: 1199 (f. 292v), 1208 (f. 292v), 1238/9 (f. 
-From 1399, a donation made to the Qannoubine monastery (Rabbula's Book of Gospels, Firenze, BML, Pluteo 1.56, f. 14r).

-From 1402, which is the colophon of the ms. BAV Vat Syr 133 (Book of Direction, called in Arabic Kitāb al-Hudā).

\subsubsection{Complete texts}

As for complete texts, the Maronites are considered to be the community that most used Garshuni throughout the Middle Ages ${ }^{74}$ and even up to the $20^{\text {th }}$ century. ${ }^{75}$ The oldest dated manuscripts are: BAV Vat Syr 133 (1402, Kitāb al-Hudā); BnF Syr 203 (1469, Kitāb al-Hudā, Treatise of Thomas of Kfarțāb, miscellaneous); BAV Vat Syr 146 (1472, Opuscules of Jean Maron); BnF Syr 225 (1475, Kitäb al-Hudā, Treatise of Thomas of Kfarțāb); Oxford Bodlean Marsh. $440 / 1$ and 2 (1488, Old Testament). ${ }^{76}$

From the $16^{\text {th }}$ century onward, the Maronites used Garshuni with abundance. I can give the example of the Maronite bishop Gabriel Ibn al-Qilāề (+ c. 1516): all his works: 19 books, 9 letters, and 16 colloquial poems (zağal) were written and preserved in Garshuni. ${ }^{77}$

It is important here to discuss the issue of two manuscripts considered till now, after Samir Khalil, ${ }^{78}$ as the oldest Garshuni Maronite manuscripts and by many scholars as the oldest Garshuni manuscripts at all.

8r), 1279 (f. 6v), 1361/2 (f. 283v-284r, 284v), 1398/9 (f. 14r). See also MENGOZZI 2008: 59-66.

${ }^{74}$ SAMIR 1982: 43; MENGOZZI 2010: 303. Moreover, COAKLEY 2001: 187, gives the $14^{\text {th }}$ century as a terminus post quem for Maronite Garshuni manuscripts. Furthermore, BRIQUEL-CHATONNET, 2005: 467, argues for the $15^{\text {th }}$ century: " un premier relevé rapide à travers les catalogues révèle l'existence de manuscrits en garshouni dès le début du $15^{\mathrm{e}}$ siècle."

75 The collection of the Lebanese Maronite Order, preserved at the Holy Spirit University of Kaslik (Jounieh-Lebanon), contains many Garshuni manuscripts from the $20^{\text {th }}$ century. The ms. OLM 3179 is one of them: it is a book of prayer, in Garshuni, written by Francis Akiki in 1967.

76 SMITH 1864: 405-409. A part is written in Garshuni by a scribe named Joseph.

${ }^{77}$ MOUKARZEL 2007.

${ }^{78}$ SAMIR 1982. 
The first case is the ms. BAV Vat Syr 146. Following the Assemanis in their catalogue, ${ }^{79}$ most scholars dated this manuscript to 1392. However, Michel Breydy rightly noted that this date was the result of manipulation. The original date was written in extenso "in the year 1783 of the Greeks" (1472 A.D.), but the word eighty was scratched by an unknown hand and the date was changed to 1703 of the Greeks (1392 A.D.). ${ }^{80}$

The second ms. is BAV Borg Ar 135. Tissérant, in his catalogue, considered it to be from $1384,{ }^{81}$ whereas Bertaina stated in his thesis that the ms. combined two parts, one from 1308 (f. 1r$99 \mathrm{v}$ ), and the other from 1384 (f. 100r-275r). ${ }^{82}$ However, this date must be later than the $15^{\text {th }}$ century. In fact, the first part includes treaties from the Maronite Gabriel Ibn al-Qilāê (+1516). Hence, the date given by Bertaina (1308) as the colophon of the first part is just a date copied from the original by a scribe. The colophon of the second part is dated 1695 without any precision of era, and the most likely explanation is that date is written according to the Gregorian calendar. It was interpreted by Tisserant to be dated from the Seleucid era and converted to become 1384 A.D.

Geographically speaking, the Maronites of Mount Lebanon were the most prolific writers of Garshuni documents, followed by Maronites from other regions of modern Lebanon as well as Aleppo and Cyprus. A dozen Maronite manuscripts were copied or written in Rome, especially by the students of the Maronite College (established in 1584). ${ }^{83}$

\subsection{Inscriptions}

The corpus of Maronite Garshuni inscriptions in Lebanon is still being studied. ${ }^{84}$ The oldest Garshuni inscription is on a painted canvas representing the Dormition (conserved at the museum of the

79 ASSEMANi 1756-1759, III: 273.

80 BREYDY 1988: 2.

81 TiSSERANT 1924: 17. He is followed by the majority of scholars who consider this codex as the oldest known dated Garshuni manuscript.

${ }^{82}$ BERTAINA 2007: 371-374.

${ }^{83}$ See GemaYel 1984.

${ }^{84}$ The CNRS - Paris and the Phoenix Center for Lebanese Studies (USEK - Lebanon) are establishing a project called RIS - Liban (Répertoire des Inscriptions Syriaques du Liban) which is an inventory of all Syriac and Garshuni inscriptions in Lebanon. 
Maronite patriarchate at Bkerke); it goes back to the year 1523.85 The inscription in stone, considered to be the oldest until further discovery, is located in Mār Šallițā-Miqbis in the region of Kesrwan, and dates back to $1628^{86}$ (whereas the oldest one in Iraq dates back to 1629). ${ }^{87}$

\subsection{Printed texts}

The history of printed Garshuni coincides with the first printing of books in Syriac, when Theseus Ambrosius published the first book using Syriac letters in 1539.88 In folio 25v, he inserted a text from the Gospel of Luke (3:23-38) in Garshuni. ${ }^{89}$

However, it is in Italy that the first book was entirely edited in Garshuni. It was a manual of catechism, ${ }^{90}$ edited by the BasaGranjon's typographic enterprise at the end of May 1580, ${ }^{91}$ and

85 LA CROIX 2006: 24, wrongly dates this Koïmesis from 1593.

${ }^{86}$ ISKANDAR 2008: 88; MOUKARZEL 2013.

${ }^{87}$ HARRAK 2010. For the $17^{\text {th }}$ century, the dates given for the Garshuni inscriptions are: 1629, 1657, 1660, 1679, 1690, 1691 (4), and 1697. For the $18^{\text {th }}$ century, the dates are: 1701, 1704, 1715, 1727, 1744 (10), 1745, 1747, 1750, 1757, 1769, 1771, 1772, 1774, 1776, 1792, 1795, 1797 , and 1800 .

88 Albonesi 1539. SMitskAMP 1992: 238-241 (n 240); COAKLEY 2006: 29-30. All the previous editions used Hebrew characters to transcribe Syriac letters.

${ }^{89}$ This printed book uses foliation and not pagination.

90 This catechism is attributed in its final draft to Fabio Bruno, companion of J.B. Eliano the papal ablegate for the Maronites. At the end of the book, we find a letter sent from the cardinal Antonio Carafa to the Maronite patriarch Michael Rizzi in which the cardinal pointed out that Pope Gregory XIII himself wanted to publish this treatise in order to retain the union of the Maronites with Rome. Eliano presented the book during the synod of Qannoubin in August 1580. For more details, see KOROLEVSKIJ [n.d.]: 7; KURI 1989: 119*, 399-447 (Publication of the Arabic text with an Italian translation).

91 Korolevskij argues about the date: "Quelle date convient-il d'assigner à la publication de cet opuscule? Celle du 7 avril 1580, répétée partout, doit être celle de l'approbation du manuscrit. Le synode de Qanubin ayant été tenu du 15 au 17 août suivant, le voyage des deux envoyés pontificaux et les préparatifs ayants demandé un mois et demi au moins, on peut fixer la date d'Impression en avril-mai 1580." KOROLEVSKIJ [n.d.]: 8. 
intended for the Maronites. That same year, the papal envoy J.-B. Eliano brought to the Maronites another book he had translated himself from Latin into Arabic (printed in Garshuni in the same year, 1580). That was the Creed of the Catholic Faith, approved by the Council of Trent, and known as the Creed of Pope Pius IV.92

The next two Garshuni works were the Gregorian calendar of $1583^{93}$ and a Maronite prayer book printed in $1584 .^{94}$ One year later, in 1585, the first Syriac book was printed and dedicated to the Maronites. This was the Book of the Burial of the Dead. ${ }^{95}$

The abundance of Garshuni in the printing of non-biblical and non-liturgical books indicates that Garshuni was, in this period, the most efficient and practical way for the Roman authorities to communicate with Christian communities, including the Maronites, in the Middle East.

Maronite printing history in Lebanon also has a preference for Garshuni. The first edited book in the Eastern part of the Ottoman Empire was a bilingual Book of Psalms (Syriac and Garshuni) edited in 1610 by the Maronite bishop Sarkis Rizzi at the monastery of Saint Anthony in Qozhāyā valley. ${ }^{96}$ The same monastery established a printing press during the $19^{\text {th }}$ century, which has produced no less than one hundred editions; all of them were in Syriac or Garshuni and none in Arabic characters. ${ }^{97}$

92 It was written in Garshuni and sent first to the Maronites. KOROLEVSKIJ [n.d.]: 23. It could be also the same text sent later to the West Syrians during the mission of Leonardo Abel in 1583. VERVLIET 1967: 24 .

93 VERVLIET 1967: 24.

${ }^{94}$ Kitäb as-sab' at șalawät al-laylìyah wan-nahärìyah likul yawm 'ala ritbat almawarinah as-suryan. See the detailed description in KOROLEvSKIJ [n.d.]: 12-15. VERVLIET 1967: 24 wrongly identified it as the Breviary. In fact, this book is similar to the byzantine Horologion and does not include the canonical hours but prayers read by lay people; the Maronites later called it Shbiyeh, a word taken from the Coptic Agpeya.

${ }^{95}$ Officium defunctorum ad usum Maronitarum S.S.D.N. Gregorii XIII Pont. Max. impensa chaldaicis characteribus impressum, Romae: Ex typographia Dominici Basae. See Vervliet 1967: 25.

${ }^{96}$ See MoukARZEL 2010-2011.

${ }^{97}$ CHeikho 1995: 30-32. 


\subsection{Reverse Garshuni}

"Reverse Garshuni" is, in the Maronite case, the writing of Syriac using Arabic letters. One of the oldest witnesses to this method is the West Syrian manuscript, BL Add. 17220, copied in 1237, throughout which many Syriac words were transcribed in the Arabic alphabet. ${ }^{98}$

A similar practice is current in Lebanon to meet pastoral needs. In the Maronite missal, for example, some prayers and hymns (Qadishat aloho, prayers of the entrance to the altar), written originally in Syriac, are also transcribed using Arabic letters to assist the full participation of the people during the liturgy.

\section{CHARACTERISTICS OF MARONITE GARSHUNI}

While it is true that Garshuni is a transcription system, it did not generate complex grammar, but rather simple general rules adopted by copyists throughout the ages. Thus, Garshuni remains totally dependent on the copyist's cultural background, the tradition of his/her religious community, and the geographical location. Maronite Garshuni did not differ from these general rules; nevertheless it improved some varieties during its evolution.

One of these varieties is the use of the emphatic Arabic letter dad [ض], which seems to have the most fluctuating representation in the history of Garshuni. In older manuscripts, it is represented by a simple Syriac dolath [?], with or without a diacritical dot. ${ }^{99}$ In later manuscripts, it is represented by the Syriac tet, generally with a dot "in its belly" [孔], but sometimes without any diacritical dot. The third type of representation is a Syriac sodeh with a dot above it [i]. In Maronite Garshuni manuscripts and in Lebanese manuscripts, in general, the use of the sodeh for the dad was only proven in the second half of the $17^{\text {th }}$ century and became common during the $19^{\text {th }}$ century. ${ }^{100}$

As for West Syrian manuscripts, the use of the sodeh is proven since the $16^{\text {th }}$ century. ${ }^{101}$ East Syrians and Chaldeans used the

\footnotetext{
98 WRIGHT 1870-1872, I: 134, gives some examples.

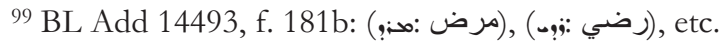

100 An example is found in DAWUD 1896: 151.

101 Among the oldest are: BL Add 21580 (1518); BAV Vat Ar 902
} (1580), etc. 
sodeh. 102 And, while the first books in Garshuni printed by Roman authorities followed the sodeh tradition ${ }^{103}$ (following the influence of some active West Syrians in Rome at that time), the first Maronite printed works followed their own tradition, the tet. 104

Another variety is found in the use of the emphatic Arabic letter $z a h[\dot{b}$, which is represented by the Syriac tet, usually with a dot above ( $)$. Sometimes it is written with a dot inside like the syriac dad (๖), and even without any diacritical mark. In these later cases, it is the reader's responsibility to know if it is the letter dad

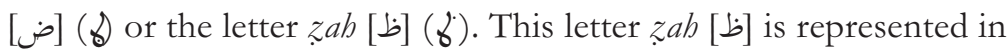
some manuscripts by a sodeh with or without a dot above. ${ }^{105} \mathrm{It}$ could also be transcribed by a dolath, as in older manuscripts. ${ }^{106}$

I draw attention here to the fact that many of the Maronite texts copied or printed between late $17^{\text {th }}$-beginning $18^{\text {th }}$ century adopted an intermediate solution, ${ }^{107}$ where both the sodeh and the tet were used to transcribe the Arabic dad [ض] or zab [b].

Other characteristics which are not consistent can be found in Garshuni manuscripts (Maronites and others):

102 See, for example, BL Rich 7176 (1683, East Syr.), Cambridge Add 3286 (1704, Chaldean), BL Add 25874 (1740, Chaldean). A rare sample of mixture use of sodeh / dàd is found in the ms. Berlin Sachau 109 (1730, Chaldean).

${ }^{103}$ The Catechism and the Creed both published in 1580 .

${ }^{104}$ The book Sab at șalawàt published in 1584.

${ }^{105}$ For example, Berlin Sachau 187 (1566, West Syr.); BL Add 23596

(1720, West Syr.); Cambridge Add 3278 (1722, West Syr.).

106 BL Add 14493 (dated from the 10 ${ }^{\text {th }}$ c. by WRIGHT 1870-1872, I:

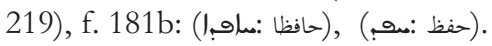

107 BL Rich 7209 (1560, West Syr.), Cambridge Dd 10.10 (1561); Berlin Sachau 187 (1566, West Syr.); BAV, Vat Ar 902 (1580, West Syr.); BL, Harl 5512 (1549, West Syr.); Cambridge Add 2005 (1579, West Syr.); Cambridge Add 3280 (1607, West Syr.); BL Rich 7206 (1681, West Syr.); Cambridge Add 2004 (1703, West Syr.); BL Rich 7207 (1732, West Syr.); Cambridge 3277 (1790, West Syr.), etc. An important Maronite example of this intermediate tradition is found in the New Testament edited by Naironus in 1703: In the introduction, the editor use the sodeh to transcribe the $d \bar{a} d$; but the in the text itself, obviously taken from an old manuscript, the tet is used to transcribe the dadd. 
-The use of two dots over the final [b] to represent the $t \vec{a}$, marbütah [0̈]. ${ }^{108}$

-The substitution of the final alif maqsürah with the Syriac

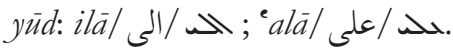

-The assimilation of làm at-tà rif, the article lam, before solar letters, especially in the oldest manuscripts: aśams (avai) instead of al-šams (لحم:ar).

-The use of Arabic šadda.

-The use of tanwin - an and -in.

-The use of Arabic short vowels: dammah, fathah, kasrah.

-The omission of the second letter in double lam: alah (الحه) instead of allah (لحده); aläbüt (Loalli) instead of al-lähüt (Loall).

-The use of yūd instead of hamza kursi l-yā': 'äyilätubum

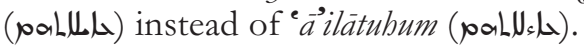

-The presence or not of the final hamza: al-masäa (الحمهماء)

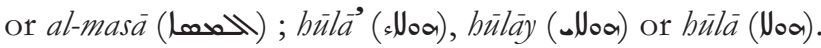

-The use of the abbreviation hyphen: الحمبه for for الحمبحه;

-The use of the numerical hyphen: 1894.

Finally, I point to the fact that the omission of diacritical marks and punctuation is often found in manuscripts, and thus, it is up to the reader to best judge what was written.

\section{CONCLUSION}

Thus, even if we are sure now that Maronite Garshuni manuscripts are not the oldest Garshuni texts anymore, it is clear that the Maronites have employed Garshuni for a long time now.

With all the attention given recently to the study of Garshuni, and especially with this first symposium dedicated to Garshuni studies, I hope that this field of research will help to better understand the evolution of Syriac and Arabic literature in the Middle East throughout the ages, and I think that now with the

108 One of the older examples is found in ms. Birmingham, Mingana 22 (1527). 
digital era we are able to consult more catalogues, manuscripts, and digital copies, which will give us the possibility to go deeper in our investigation about Garshuni and its literature.

\section{BIBLIOGRAPHY}

AlbONESI T.A., 1539. Introductio in Chaldaicam linguam, Syriacam, atque Armenicam, et decem alias linguas. Characterum differentium Alphabeta, circiter quadraginta, et eorundem invicem conformatio. Mystica et Cabalistica quamplurima scitu digna. Et descriptio ac simulachrum Phagoti Afranii. Pavia: excudebat J. M. Simoneta.

AMIRA G., 1596. Grammatica Syriaca sive Chaldaica. Romae: In Typographia Linguarum externarum, apud Iacobum Lunam.

ASSEMANI J.S. \& ASSEMANI S.E., 1756-1759. Bibliothecae apostolicae vaticanae codicum manuscriptorum catalogus in tres partes distributes..., 3 vols. Romae: ex Typographia Linguarum Orientalium.

Assemanus S.E., 1742. Bibliotheca Medicece Laurentiance et Palatina Codicum mms. Orientalium Catalogus. Florentix: Ex Typographio Albiziniano.

ASSFALG J., 1963. Syrische handschriften. Syrische, karshunische, christlichpalästinische, neusyrische und mandäische Handscbriften. Verzeichnis der orientalischen Handschriften in Deutschland V. Wiesbaden: Franz Steiner.

ASSFALG J., 1982. "Arabische Handschriften in syrischer Schrift (Karšūnī)", in FISCHER W. (ed), Grundriss der arabischen Philologie. Band 1: Sprachwissenschaft. Wiesbaden: Harrassowitz, p. 297-302, 315.

Assfalg J., 1991. "Karšūn̄i," in Assfalg J. and KrÜger P., Petit dictionnaire de l'Orient chrétien. Brepols, p. 280.

BAKHACHE J., 1936. "Ma l-murād bi-lafẓat karšūn̄ī aw garšūnī," in al-Hub was-saläm, année 1, vol. 6, nov.-déc., p. 271-276.

Bertaina D., 2007. An Arabic Account of Theodore Abu Qurra in Debate at the Court of Caliph al-Ma'mun: A Study in Early Christian and Muslim Literary Dialogues. PhD Dissertation, The Catholic University of America.

BLAU J., 1981. The Emergence and Linguistic Background of JudaeoArabic. A Study of the Origins of Middle Arabic, $2^{\text {nd }}$ ed., Jerusalem: Ben-Zvi Institute. 
BOBZIN H., 1991. "Über eine bisher unbekannte europäische bezeugung des terminus 'Karšūnì' im 16. Jahrhundert," Journal of Semitic Studies, 36/2, p. 259-261.

Borbone P.G., 2010. "L'itinéraire du "codex de Rabbula" selon les notes marginales," in BRIQUEL ChATONNET F. et DEBIE, M. (éd.), Sur les Pas des Araméens Chrétiens. Mélanges Offerts à Alain Desreumaux. Paris: Geuthner (Cahiers d'études syriaques 1), p. 169-180.

BRAIDA E., 2009. "Duas lineas olearum prope oppidum Besciara. Le localizzazioni del codice siriaco Pluteo 1.58 (ca. IX s.) della biblioteca Medicea Laurenziana di Firenze." Eggitto e Vicino Oriente, 32, p. 255-269.

BRAIDA E., 2010. Le Annotazioni Garšuñi nei Manoscritti Siriaci e Cristiano-palestinesi. Tesi di Dottorato di Ricerca, Università degli Studi di Pisa.

BRAIDA E., 2012. "Garshuni Manuscripts and Garshuni Notes in Syriac Manuscripts," Parole de l'Orient 37, p. 181-198.

BREydy M., 1988. Jean Maron: exposé de la foi et autres opuscules, vol. 2. Corpus Scriptorum Christianorum Oreintalium 498. Scriptores Syri 210. Louvain: Peeters.

BRIQUEL-CHATONNET F., 1997. Manuscrits syriaques de la Bibliothèque nationale de France $\left(n^{\circ}\right.$ 356-435, entrés depuis 1991), de la Bibliothèque Méjanes d'Aix-en-Provence, de la Bibliothèque municipale de Lyon et de la Bibliothèque nationale de Strasbourg. Catalogue. Paris: Bibliothèque nationale de France.

Briquel Chatonnet F., 2005. "De l'intérêt de l'étude du garshouni et des manuscrits écrits selon ce système," in Gobillot G. et URvoy M.-T. (éd.), L'Orient chrétien dans l'empire musulman. Hommage au professeur Gérard Troupeau. Éditions de Paris, p. 463-475.

Briquel-Chatonnet F., Desreumaux A. et Binggeli A., 2006. "Un cas très ancien de garshouni? Quelques réflexions sur le manuscrit BL Add. 14644," in BORBONE P. G., Mengozzi A. et Tosco M. (éd.), Loquentes linguis. Studi linguistici e orientali in onore di Fabrizio A. Pennacchietti. Wiesbaden: Harrassowitz Verlag, p. 141-148.

BrockelmanN C., 1927. "Karshūnī," EI', vol. II. Leiden: Brill, p. 775. 
CHeIKHO L. 1995. Tärīh fan at-tibäa ah fì al-mašriq, $2^{\text {nd }}$ ed. Beirut: Dar al-Mashriq.

COAKLEY J.F., 2001. "Garshuni," in SAWYER J.A. (ed.), Concise Encyclopedia of Language and Religion, Elsevier, p. 186-187.

COAKLEY J.F., 2006. The Typography of Syriac. A Historical Catalogue of Printing Types, 1537-1958. London: Oak Knoll Press and the British Library.

DAWUD I., 1896. Kitāb al-lum ah ašs-sabìya fì nabū al-lugia as-suryānìya éà kilä madhabay al-garbìyin wa aś-sarqizyin. Title given also in French: Grammaire de la langue araméenne selon les deux dialectes syriaque et chaldaïque, $2^{\text {nd }}$ ed. Mossoul: Imprimerie des Pères Dominicains.

DirYAN Y., 1904. “Aṣl lafẓat karšūnī,” Machriq 7, p. 785-790, 880.

Feghali J., 1962. Histoire du droit de l'Eglise maronite. Vol. 1: Les conciles des XVTe et XVIT siècles. Paris: Letouzey et Ané.

GEMAYEL N., 1984. Les échanges culturels entre les Maronites et l'Europe: du Collège Maronite de Rome (1584) au Collège de Ayn Warqa (1789), 2 vols. Beyrouth.

HARRAK A., 2010. Recueil des inscriptions syriaques, tome 2, Iraq: Syriac and Garshuni inscriptions, 1 (Text), 2 (Plates). Paris: Académie des Inscriptions et Belles Lettres.

HARRAK A., 2011. Catalogue of Syriac and Garshuni manuscripts. Manuscripts owned by the Iraqi Department of Antiquities and Heritage. Corpus Scriptorum Christianorum Orientalium 639. Subsidia 126. Louvain: Peeters.

Huntington R. 1704. Admodum reverendi \& doctissimi viri, D. Roberti Huntingtoni, Episcopi Rapotensis, Epistola: et veterum Mathematicorum, Gracorum, Latinorum, et Arabum, Synopsis: Collectore Viro Clarissimo et Doctissimo, D. Edwardo Bernardo... Scriptore Thoma Smitho, Londini.

ISKANDAR A.-J., 2008. Épigraphie syriaque au Liban. I: Catalogue des épigraphes syriaques au Liban du Haut Moyen Age à 1925. Louaizé: NDU.

JABRE-MOUAWAD R., 2005. "Les notices syriaques maronites de l'époque des croisades (XII -XIII e s.)," in CHAHWAN A. (éd.), Mélanges offerts à l'abbé Jean Tabet. Kaslik: Publications de l'Université Saint-Esprit de Kaslik (Institut de liturgie 34), p. 131-158. 
JABRE-MOUAWAD R., 2012. "Maronites and the Garshuni script," Parole de l'Orient 37, p. 223-240.

KESSEL G., 2012. "The importance of the manuscript tradition of the 'Book of Grace' for the study of Garšunnī," Parole de l'Orient 37, p. 199-222.

KOROLEVSKIJ C., [n.d.]. La typographie médicéenne et les publications orientales à Rome à la fin du XVTe siècle. Typewritten text preserved at the Biblioteca Apostolica Vaticana. Riserva.III.97.

KURI S., 1989. Monumenta Proximi-Orientis, I: Palestine, Liban, Syrie, Mésopotamie (1523-1583). Roma: Institutum Historicum Societatis Iesu.

LA Croix A.-M. de, 2006. Icônes arabes, mystères d'Orient, Éditions grégoriennes.

Lebanese Synod = Al-Mağma' al-iqlìmī al-lad̄̄ 'aqadabu fì Ğabal Lubnān batriyark țäifat as-suryān al-mawärina al-ințākì..., translated from latin by NAJM Y., Jounieh: Mațba 'at al-Arz, 1900.

LEROY J., 1967. "Un témoignage inédit sur l'état du monastère des Syriens au Wadi 'n Natrûn au début du XVIe siècle," Bulletin de l'Institut Français d'Archéologie Orientale 65, p. 15-19.

LEWIS A.S. and GIBSON M.D., 1899. The Palestinian Syriac Lectionary of the Gospels: Re-Edited from two Sinai Mss. And from P. De Lagarde's Edition of the "Evangeliarum Hierosolymitanum." London: Kegan Paul, Trench, Trübner \& Co.

MAI A., 1831. Scriptorum veterum nova collectio, vol. V: Codices chaldaici sive syriaci vaticani assemaniani. Romae: Typis Vaticanis Press. [VS 258-459].

Margoliouth G., 1873. Descriptive List of Syriac and Karshunic Manuscripts in the British Museum Acquired since 1873. London.

MengozZi A., 2008. "Le annotazioni in lingua araba sul codice di Rabbula," in BERNABO M. (a cura di), Il Tetravangelo di Rabbula. Firenze, Biblioteca Medicea Laurenziana, Plut.I.56. L'illustrazione del Nuovo Testamento Nella Siria del VI Secolo. Roma: Edizioni di Storia e Letteratura: 59-66.

MengozZI A., 2010. "The History of Garshuni as a Writing System: Evidence from the Rabbula Codex," in FALES F. M. \& GRASSI G. F. (eds), CAMSEMUD 2007. Proceedings of the 13th Italian Meeting of Afro-Asiatic Linguistics, held in Udine, May 21st- 
24th, 2007. Padova: S.A.R.G.O.N. Editrice e Libreria, p. $297-$ 304.

MengozZI A., 2011. "Garshuni," in Brock S., Butts A., and KIRAZ G. (eds.), Gorgias Encyclopedic Dictionary of the Syriac Heritage Piscataway: Gorgias Press, p. 172-173.

MinganA A., 1928. "Garshūni or Karshūni?," Journal of the Royal Asiatic Society 4, p. 891-893.

Mingana A., 1933. Catalogue of the Mingana Collection of Manuscripts now in the Possession of the Trustees of the Woodbrooke Settlement, Selly Oak, Birmingham, vol. I: Syriac and Garshuni Manuscripts. Cambridge: W. Heffer and Sons.

MOUKARZEL J., 2007. Gabriel Ibn al-Qilāì († ca 1516): approche biographique et étude du corpus. Kaslik: Publications de l'Université Saint-Esprit de Kaslik.

MOUKARZEL J., 2008. "Remarques sur une note garshouni du ms. BL. Add. 14644," in Mélanges offerts au Père Abbé Paul Naaman. Kaslik: Publications de l'Université Saint-Esprit de Kaslik (Institut d'Histoire 14), 81-100.

MOUKARZEL J., 2010-2011. "Le psautier syriaque-garchouni édité à Qozhaya en 1610. Enjeux historiques et présentation du livre," Mélanges de l'Université Saint-Joseph 63, p. 511-566.

MoukARZEL J., 2013. "L'inscription de Mar Challita-Mouqbes (Liban, 1628) et l'usage du garchouni en épigraphie," Semitica et Classica 6: 277-284.

MOUKARZEL J., 2014. "Le garshuni. Remarques sur son histoire et son evolution," in DEN HEIJER J., SCHMIDT A., and PATARIDZE T. (eds), Scripts Beyond Borders. A Survey of Allographic Traditions in the Euro-Mediterranean World. Publications de l'Institut Orientaliste de Louvain 62, Louvain: Peeters, 107138.

NAIRONus F. (ed.), 1703. Sacrosancta Jesu Christi Evangelia jussu sacra congregationis de Propaganda fide ad usum Ecclesice nationis maronitarum edita. Romæ: Typis Sacrae Congregationis de Propaganda Fide.

RENAN E., 1863. Histoire générale et système comparé des langues sémitiques, 3 e éd. Paris: Imprimerie impériale.

Río SÁNCHEZ F., 2004. "El árabe karshūnī como preservación de la identidad siríaca," in BÁdenas DE LA PEÑA P. et ali (ed.), 
Lenguas en Contacto: El testimonio escrito. Madrid: Consejo Superior de Investigaciones Cientificas: 185-194.

Rio SANCHEZ F., 2010. Manuscrits en Arabe Karšuni conservés dans la bibliothèque des Maronites d'Alep, Syrie. Piscataway: Gorgias Press.

Río SÁNCHEZ F., 2013. "Arabic-Karshuni: an attempt to preserve maronite identity: the case of Aleppo," The Levantine Review 2, p. 3-11.

Rosen F. and Forshall J., 1838. Catalogus codicum manuscriptorum orientalium qui in Museo Britannico asservantur, pars 1a: Codices Syriacos et Carshunicos amplectens. London.

SACHAU C.E., 1899. Verzeichniss der syrischen Handschriften (Die Handschriften - Verzeichnisse der Königlichen Bibliothek zu Berlin 23), 2 vols. Berlin: A. Asher and Co.

SALEM M., 1988. Al-Karšuninyah: ribät luganà bayna al-arabiyat wa lsuryānìyat. Le Caire: Dār al-fikr al-earabī.

SAMIR K., 1982. "La tradition arabe chrétienne. État de la question, problèmes et besoins," in SAMIR K. (éd.), Actes du premier congrès international d'études arabes chrétiennes (Goslar, septembre 1980). (OCA 218), Roma.

[SHUSHAN S.], ed., 1782. Horae diurnae et nocturnae ad usum orientalium. Romae: Typis Pauli Junchi.

SMITH R.P., 1864. Catalogi codicum manuscriptorum bibliothecae Bodleianae, pars VIa. Codices Syriacos, Carshunicos, Mandaeos complectens. Oxford.

Smitskamp R., 1992. Philologia Orientalis. A Description of Books Illustrating the Study and Printing of Oriental Languages in $16^{\text {th }}$ and $17^{\text {th }}$ Century Europe. Leiden: Brill.

TISSERANT E., 1924. Inventaire sommaire des manuscrits arabes $d u$ fonds Borgia à la Bibliothèque Vaticane. Roma.

Troupeau G., 1978. “Karshūnī,” EI 4, p. 699.

VAN LANTSCHOOT A., 1965. Inventaire des manuscrits syriaques des fonds Vatican, 490-631 [faute d'imprimerie, c'est plutôt 460-631], Barberini oriental et Neofiti. Biblioteca Apostolica Vaticana, Citta del Vaticano. (Studi e Testi, 243).

VERVLIET H.D.L., 1967. "Robert Granjon à Rome (1578-1589). Notes préliminaires à une histoire de la typographie romaine à 
la fin du XVIe siècle," Bulletin de l'Institut historique belge à Rome 38, p. 177-231.

WRIGHT W., 1870-1872. Catalogue of the Syriac Manuscripts in the British Museum Acquired since the Year 1838, 3 vols. London.

Wright W., 1901. A Catalogue of the Syriac Manuscripts preserved in the Library of the University of Cambridge, 2 vols. Cambridge: University Press.

ZotenberG H., 1874. Catalogues des manuscrits syriaques et sabéens (Mandaïtes) de la Bibliothèque Nationale. Paris: Imprimerie Nationale. 